\title{
sciendo
}

\section{USE OF DUCKWEED (LEMNA L.) IN SUSTAINABLE LIVESTOCK PRODUCTION AND AQUACULTURE - A REVIEW*}

\author{
Marcin Sońta, Anna Rekiel, Martyna Batorska` \\ Department of Animal Breeding and Production, Warsaw University of Life Sciences - SGGW, \\ Ciszewskiego 8, 02-786 Warsaw, Poland \\ •Corresponding author: martyna_batorska@sggw.pl
}

\begin{abstract}
The aim of this study was to determine the possibility of using duckweed in sustainable livestock production and aquaculture. Duckweed is a small plant which grows in water and is exploited in biotechnology, dietetics, phytotherapy, and ecotoxicology. It is also used for biological wastewater treatment, and for biogas and ethanol production. This study provides the characteristics of duckweed and presents results indicating its applicability in livestock feeding. Duckweed is a rich source of proteins and amino acids, and contains many macro- and micronutrients as well as vitamins and carotenoids. Unfortunately, it accumulates considerable amounts of toxic metals and compounds from the aquatic environment, which may limit its use as a feed ingredient. Fresh or dried duckweed is willingly consumed by animals (poultry - laying hens, broiler chickens, ducks; cows, sheep, goats, swine, fish) and is a valuable protein source to them. It has been scientifically demonstrated that its use in moderate amounts or as a partial replacement of other protein feed materials, including soybean meal, has a beneficial effect on the productivity, fattening, and slaughter performance of livestock and poultry as well as on the quality of their meat and eggs. Research addressing duckweed use as a feed ingredient should focus on developing various growth media technologies, including the use of slurry digestate, to obtain high biomass yields. Another research direction should be to determine risks in the production chain (collection, processing), which limit its use in monogastric and ruminant diets.
\end{abstract}

Key words: duckweed, feed, protein source, farm animals, aquaculture

Duckweed (Lemna L.) has for years been the subject of interest in many regions of the world. Its use in folk medicine has been scientifically substantiated. It exhibits cholagogic, carminative, expectorant, diaphoretic, diuretic, and anticarcinogenic

*Study funded: Cradle to Cattle farming project, 8th Joint Call for Research and Development Proposals of the ERA-NET Bioenegry, Integrated Biorefinery Concepts, Contract no.: BIOENERGY/CtoCfarming/03/2016. 
properties. For more than a decade, duckweed has been successfully used in biotechnology to produce biologically active compounds of importance in dietetics, phytotherapy, and phytocosmetics (Czerpak and Piotrowska, 2005). In turn, Chhabra et al. (2011), Vladimirova and Georgiyants (2014), Bandurska et al. (2016) reported its usability in biopharmaceuticals production, whereas Czerpak and Piotrowska (2005) concluded that Wolffia arrhiza could and should be used in combination with other Lemnaceae species and some representatives of Chlorophyta in vegetation constructed wetlands. According to Piotrowska et al. (2009, 2010), Wolffia arrhiza (L.) Horkel ex Wimm, a representative of the Lemnaceae family, could be used for phytoextraction of heavy metals from the aquatic environment. The scientifically proven phytoremediation properties of duckweed have caused it to be used around the world, including in Poland, for biological wastewater treatment. Duckweed is also used in ecotoxicology, and in biogas and ethanol production (Bień and Bień, 2010; Romanowska-Duda and Pszczółkowski, 2013; Verma and Suthar, 2014; Zhao et al., 2014; Cui and Cheng, 2015; Sikora and Malinowski, 2015).

A search for alternative protein sources to replace soybean meal in animal diets has triggered a renewed interest in the use of duckweed. In the 1960s and 1970s, this fodder plant was well known and used in Poland to feed waterfowl and pigs (Lassociński, 1979). Many researchers have recognized it as a source of protein for farm animals and aquaculture (Haustein et al., 1994; Bairagi et al., 2002; Goopy and Murray, 2003; Moyo et al., 2003; Khandaker et al., 2007; Effiong et al., 2009; Hasan and Chakrabarty, 2009; Akter et al., 2011; Mwale and Gwaze, 2013), and in the future possibly also for humans (Appenroth et al., 2017). Duckweed is also a very good food for swans and other Anseriformes species. According to Chojnacka (2006), it can be used to manufacture mineral supplements for animals. A duckweed-based concentrate was used in a feeding trial with piglets (Rojas et al., 2014). As early as in 2005, Czerpak and Piotrowska proposed using Wolffia arrhiza to produce feed rich in protein, starch, vitamins, hormones, and mineral salts.

Considering the above, this study aimed to provide the characteristics of duckweed and to determine its suitability, as supported by research, for the use in sustainable livestock production and aquaculture.

\section{Characteristics and classification of duckweed}

Duckweed (Lemna L.; family Lemnaceae) is a small, free-floating aquatic plant that forms mats on or beneath the surface of water. Cosmopolitan in range, it grows best in eutrophic (nutrient-rich) waters. Its leaves are small, often less than $5 \mathrm{~mm}$ in length, either single or in groups of two or three. Lemna trisulca has a branched structure and grows submerged (FAO 1999; Newman, 2013). The Lemnaceae family comprises 38 species, of which 5 are found in Poland, i.e.: gibbous duckweed (Lemna gibba L.), lesser duckweed (Lemna minor L.), star duckweed (Lemna trisulca L.), turion duckweed (Lemna turionifera Landolt), and an invasive species - least duckweed (Lemna minuta Kunth) (Table 1). Its first occurrence in Poland was reported in 2007 (Wójciak and Urban, 2007; Banaszek and Musiał, 2009). 


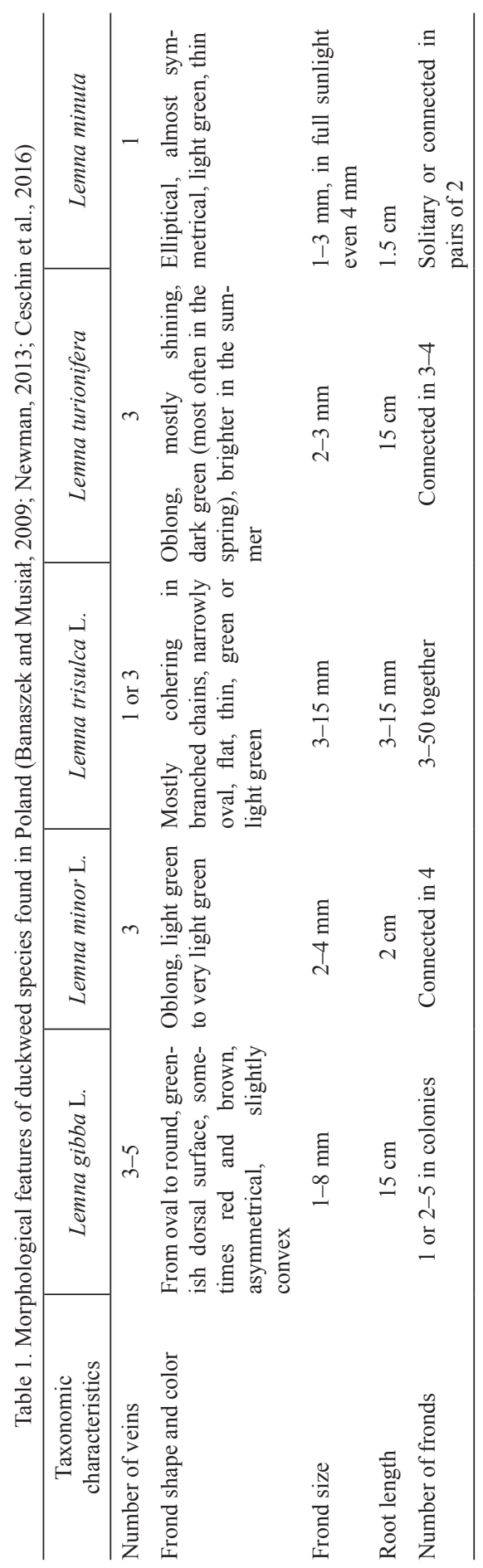




\section{Chemical composition of duckweed}

Dry matter content of duckweed ranges from 3 to 14\%. Contents of protein and other ingredients in dry matter also vary widely depending on growth media quality. The content of protein accounts for $7-45 \%$ (most often $20-45 \%$ ), fat for $2-9 \%$, fiber for $12-28 \%$, and carbohydrates for $14-44 \%$ in dry matter (FAO, 1999; Iqbal, 1999; Olorunfemi et al., 2006; Hasan and Chakrabarty, 2009). Duckweed is capable of absorbing many macro- and micronutrients from water, such as $\mathrm{Ca}, \mathrm{Cl}, \mathrm{K}, \mathrm{Na}, \mathrm{Si}, \mathrm{N}$, H, C, Fe, Mg, Mn, Al, Si, B, P, Cu, and Zn (FAO, 1999; Chojnacka, 2006; Showqi et al., 2017). This plant contains amino acids, A, B and $E$ group vitamins and carotenoids, which is its additional advantage (FAO, 1999; Chojnacka, 2006; Showqi et al., 2017). Duckweed is effective in absorbing various components from the aquatic environment, including harmful heavy metals. According to FAO's report (1999), the contents of such elements as $\mathrm{Cd}, \mathrm{N}, \mathrm{Cr}, \mathrm{Zn}, \mathrm{Sr}, \mathrm{Co}, \mathrm{Fe}, \mathrm{Mn}, \mathrm{Cu}, \mathrm{Pb}, \mathrm{Al}$, and $\mathrm{Au}$ in duckweed do not pose threat to human or animal health, and therefore it can be used as a supplement in feed mixtures for poultry and livestock.

\section{Effect of environmental factors on biomass production}

The growth rate, chemical composition and amount of biomass harvested from duckweed depend on many factors. These include nutrient concentration in water, water temperature and $\mathrm{pH}$, sun exposure and day length, and wind speed.

Duckweeds grow at water temperatures ranging from 6 to $33^{\circ} \mathrm{C}$, and at $\mathrm{pH}$ of 5 to 9. The optimum growth conditions for high biomass production are water temperatures between 20 and $28^{\circ} \mathrm{C}$ and $\mathrm{pHs}$ between 6.5 and 7.5 . To prevent excessive changes in water temperature, duckweed ponds should be at least $30-50 \mathrm{~cm}$ deep. Because duckweed is susceptible to being moved by wind and to water currents in water basins in which it grows, wind speed in the duckweed-growing area should not exceed $0.3 \mathrm{~m} / \mathrm{s}$. To avoid wind drifts, water basins are divided into cells or compartments ( 2 to $5 \mathrm{~m}$ wide by 4 to $8 \mathrm{~m}$ long), which stabilizes the growth conditions (FAO, 1999; Iqbal, 1999).

Duckweed may utilize many nitrogen compounds found in the water in which it grows. The most important of these is ammonium ion $\left(\mathrm{NH}_{4}^{+}\right)$, which is the main precursor for duckweed growth. The results of studies performed at the University of New England, Armidale, Australia, indicate that N concentration exceeding $60 \mathrm{ml} / 1$ in an aquatic environment is toxic to duckweed, which is probably due to the high level of free ammonia in water the optimum concentration of which is $10-15 \mathrm{ml} / \mathrm{l}$. Duckweed can concentrate around $1.5 \%$ of phosphorus $(\mathrm{P})$ in dry matter. Its growth is possible with both high and low concentrations of this element. For normal growth, it also requires small amounts of potassium (FAO, 1999; Iqbal, 1999; Rooijakkers, 2016). Duckweed can grow in different environments because it may absorb and accumulate various minerals.

Duckweed is commercially produced mainly in tropical countries, where meal is produced from it after dehydration and deoiling (Haustein et al., 1994; Bairagi et al., 2002). It is often fed to animals in the form of a natural green biomass. Duckweed production can provide 4 to 5 times as much protein per hectare as soybean cultivation does. Another advantage of duckweed is that it is not genetically modified, 
contains no gluten, and requires no farmland nor chemical fertilizers (Zawadzki, 2016).

\section{Risks and benefits}

Duckweed accumulates many heavy metals (cadmium, chromium, lead), which can threaten its normal growth as well as the health of animals and humans. Heavy metals can enter the food chain. To prevent this, their levels should be monitored during duckweed production for feedstuffs. Absorption of heavy metals depends on their chemical form and on the life form of duckweed (floating, suspended on the water surface, rooted or not) (Iqbal, 1999; Chandra and Kulshreshtha, 2004). The use of natural water resources, household sewage, and livestock waste for duckweed production does not entail such a risk because they contain low concentrations of the above heavy metals. Studies concerning contents of various elements in duckweed, including $\mathrm{Cd}, \mathrm{N}, \mathrm{Cr}, \mathrm{Zn}, \mathrm{Sr}, \mathrm{Co}, \mathrm{Fe}, \mathrm{Mn}, \mathrm{Cu}, \mathrm{Pb}, \mathrm{Al}$, and even $\mathrm{Au}$ concluded that when their contents are low, duckweed may provide a good source of trace elements for farm animals (FAO, 1999; Spiegel et al., 2013).

\section{Duckweed in livestock production}

Duckweed is a good feed supplement in diets for monogastric and ruminant animals. Its advantage over other protein sources is that it is characterized by better availability and absorption of amino acids, including lysine and methionine, as well as of vitamins. It is rich in leucine, threonine, valine, isoleucine, and phenylalanine (Goopy and Murray, 2003). Many studies have confirmed the appropriateness of feeding duckweed to farm animals: poultry - ducks, laying hens, and broiler chickens (Haustein et al., 1992; Samnang, 1999; Ahammad et al., 2003; Khang, 2003; Khandaker et al., 2007; Akter et al., 2011; Mwale and Gwaze, 2013); pigs (Rodríguez and Preston, 1996; Du et al., 1997; Men et al., 1997; Van et al., 1997; Nguyen, 1998; Gutierrez et al., 2001; Ly et al., 2002; Du et al., 2009; Mohedano et al., 2012; Gwaze and Mwale, 2015); ruminants - cattle, sheep, and goats (Rusoff et al., 1978, 1980; Sansoucy, 1995; Huque et al., 1996); as well as fish and shrimps in aquaculture (Hassan and Edwards, 1992; Yilmaz et al., 1994; Leng et al., 1995; Effiong et al., 2009).

\section{Poultry-broiler chickens}

Haustein et al. (1992) used dried duckweed in Titan broiler diets. The birds were fattened for 6 weeks in two stages divided into 4 weeks (stage 1) and 2 weeks (stage $2)$. At stage 1 , control birds were fed a diet without duckweed ( $0 \mathrm{~g} / \mathrm{kg})$, whereas experimental birds received diets containing 100, 150, 200, 250 or $300 \mathrm{~g} / \mathrm{kg}$ duckweed. At the end of stage 1, each group was divided into two sub-groups. At stage 2, broilers were fed either a control diet (no duckweed) or experimental diets with the same proportion of duckweed as in stage 1 of the experiment. The birds fed diets with duckweed levels over $150 \mathrm{~g} / \mathrm{kg}$ showed poorer production results, namely decreased feed intake and body weight gain. In turn, the broilers fed the control diet reached much higher body weight gains and feed intake as well as a better feed conversion ratio compared to the birds fed the duckweed-containing diets. At the final stage of 
fattening (last 2 weeks), the broilers fed the control diet (no duckweed) demonstrated normal or compensatory growth.

Haustein et al. (1994) administered maize diets supplemented with 10, 15 or $25 \%$ dried duckweed to Titan and Arbor Acres broilers. Body weight gains of the broilers fed a $15 \%$ duckweed diet were comparable to those of the control broilers ( $0 \%$ duckweed). A 25\% duckweed supplement deteriorated body weight gains and reduced feed intake. The same authors investigated also if duckweed can be used as an additional protein source for broilers at commercial farms. Using a standard diet (control $-0 \%$ duckweed) and an experimental diet (5\% duckweed), they achieved a positive final outcome indicated by higher body weights reached by the experimental birds at the end of fattening compared to the control birds.

In an experiment with commercial Vencobb broiler chickens (Ahammad et al., 2003), sesame oil cake was replaced in experimental diets with $0,3,6$ or $9 \%$ dried duckweed. The diets were isonitrogenous and isoenergetic. Fattening was completed after 6 weeks. The addition of 3 or $6 \%$ duckweed to the diets improved final body weight, feed conversion and profitability compared to $0 \%$ and $9 \%$ of duckweed. Poorer results were achieved upon sesame oil cake replacement by $9 \%$ duckweed in diet.

Different results were reported by Kabir et al. (2005) who administered diets containing $0,4,8$ or $12 \%$ of dried duckweed meal to Vencobb broilers until 42 days of age. The control birds ( $0 \%$ duckweed meal) achieved the best production performance, whereas increasing duckweed meal contribution in the diet elicited negative effects in experimental broilers, including slower body growth (1.39 kg vs $1.02-1.28$ $\mathrm{kg}$ ), lower feed intake (2.50 kg/broiler vs $2.31-2.46 \mathrm{~kg} / \mathrm{broiler})$, lower feed conversion ratio (1.69 kg vs $2.11-2.51 \mathrm{~kg}$ ), as well as lower consumption of protein and energy. From these findings, the authors have concluded that the inclusion of duckweed meal in the broiler diet is not recommended, but further study is needed to provide the final recommendation for using duckweed meal at a low level as an unconventional feed ingredient for broilers.

\section{Poultry - laying hens}

In a 16-week experiment, Akter et al. (2011) fed Star Cross Brown laying hens diets in which the proportions of rice polish and fish meal were decreased with increasing proportions of dried duckweed: $0 \mathrm{~g} / \mathrm{kg}$ (control diet) and 50, 70, 110, 130, and $150 \mathrm{~g} / \mathrm{kg}$ of the diet (experimental diets). No differences were observed between the groups in such traits as body weight, egg weight, and livability. With the increasing proportion of duckweed in the diet (from 0 to $150 \mathrm{~g} / \mathrm{kg}$ ), feed intake $(759$ g vs $713 \mathrm{~g}$ ), egg production (42.9 mass/g/egg/day vs $33.5 \mathrm{mass} / \mathrm{g} / \mathrm{egg} /$ day) and feed conversion ratio $(2.54 \mathrm{~kg}$ vs $3.04 \mathrm{~kg})$ decreased. The external and internal quality characteristics of eggs did not differ among groups. Yolk colour score increased with an increased level of duckweed meal in the diet, reaching the highest value (4.5) for eggs from layers receiving the diet with $150 \mathrm{~g} / \mathrm{kg}$ duckweed. Duckweed was found to be a good source of protein for laying hens without any harmful effects on production performance up to $130 \mathrm{~g} / \mathrm{kg}$ level and on egg quality characteristics up to $150 \mathrm{~g} / \mathrm{kg}$ level. 
Anderson et al. (2011) replaced soybean meal with 12.5\% duckweed to determine its effects on production results and egg quality of Hy-Line laying hens. Birds in the control group (C) were fed a feed mixture containing maize, fat, soybean meal, wheat bran, and a mineral-vitamin mix. In the experimental group (E), the only change was soybean meal replacement in the feed mixture with $12.5 \%$ of duckweed. The use of duckweed (group E) did not change egg production (group E - 60 eggs per hen) level compared to the $\mathrm{C}$ group (59 eggs per hen). No differences were observed in nutrient composition of eggs except for a higher level of omega-3 acids in eggs from $\mathrm{E}(0.15 \%)$ compared to $\mathrm{C}(0.09 \%)$ group of hens (Anderson et al., 2011).

Witkowska et al. (2012) replaced inorganic salt (control group) with dried duckweed enriched with trace elements in diets for Lohmann Brown layers. If duckweed was fed to the birds, egg quality parameters increased, including shell thickness, total concentration of trace elements in eggs, Co content in egg yolk and shell, $\mathrm{Cr}$ content in yolk, and $\mathrm{Cu}$ and $\mathrm{Zn}$ contents in albumen and yolk (control group), but in the experimental groups, $\mathrm{Cd}$ content in yolk and albumen as well as $\mathrm{Pb}$ content in blood samples were lower than in the control group. The use of dried duckweed in layer diets proved beneficial. The authors suggested that duckweed used as a new biological supplement could be a good and cheaper alternative to inorganic dietary additives.

\section{Poultry-ducks}

Ngamsaeng et al. (2004) used fresh water spinach and fresh duckweed in rice diets for Muscovy ducks. There were three treatments: group E1 received water spinach plus broken rice (80:20), group E2 received duckweed plus broken rice (80:20), and group E3 received water spinach and duckweed plus broken rice (35:45:20). Daily weight gain was the lowest in E1 (6.2 g) and the highest in E2 (22.4 g) ducks. Feed conversion ratio was poorer in birds fed E1 and E3 diets (respectively $9.1 \mathrm{~g}$ $\mathrm{DM} / \mathrm{g}$ body weight gain and $4.3 \mathrm{~g} \mathrm{DM} / \mathrm{g}$ body weight gain) compared to these administered E2 diet (3.8 g DM/g body weight gain). The use of duckweed in duck diets was considered advisable.

Khanum et al. (2005) investigated the effect of fresh duckweed fed to Xinding ducks on their growth performance and carcass characteristics. The control group (C) received a commercial compound feed. Ducks from the experimental group 1 (E1) were fed $50 \%$ of the control diet plus freshly collected duckweed on an ad libitum basis. Ducks from the experimental group 2 (E2) received 50\% of the control diet and were allowed to forage duckweed in a lagoon. Ducks from the experimental group 3 (E3) were restricted to foraging fresh duckweed in the lagoon only. All the birds from group E3 died within the first 3 weeks of foraging. It was concluded that duckweed does not meet the nutrient requirement for maintenance and cannot be provided as the only feed in duck diets. At the end of the trial, the final body weight (E2 - $1256 \mathrm{~g}$ and E3 - $1189 \mathrm{~g})$ and the daily body gain (E2 - $6.53 \mathrm{~g} /$ day and E3 $6.28 \mathrm{~g} /$ day) of the birds were considerably lower in the experimental groups compared to the control group (E1 - $1345 \mathrm{~g}$ and $9.09 \mathrm{~g} /$ day). Duckweed inclusion to the diet for ducks caused a decrease in the analyzed parameters of birds growth, but had no negative impact on the slaughter value of their carcasses. 
Khandaker et al. (2007) conducted an experiment in which they replaced mustard oil cake in Jinding duck diets with dried duckweed (control group - 0\%, experimental groups 5, 10 or $15 \%$ dried duckweed). Duckweed had no significant influence on body weight gains, egg weight, and feed conversion ratio. Its increased contribution in the diet for ducks caused significant deterioration of egg production indices (total number of produced eggs and egg mass production), but reduced feeding costs, which improved production economics.

Pigs

In piglet diets, soybean meal was replaced with $0 \%, 20,40$ or $60 \%$ of dried duckweed (Moss, 1999). The supplemented animals exhibited high body weight gains and feed intake. Growing piglets were not averse to consuming duckweed diets. Daily body weight gains of the piglets receiving the 40 and $60 \%$ duckweed diets were greater than those of the control animals receiving soybean meal as the only source of protein. The body weight gains of control pigs and experimental pigs receiving $20 \%$ duckweed were similar. Under long-term feeding, the highest body weight was achieved by the animals receiving the highest duckweed supplement.

In an experiment conducted by Du (1998), growing pigs (Large White $\times$ Mong Cai) from the control group (C) were fed sweet potato vines. The experimental animals (E) received duckweed (Lemna minor) instead of potato tops. The consumption of fresh duckweed (around $1.5 \mathrm{~kg} /$ day/animal) had a favorable effect on the body weight gains of pigs. Compared to the animals from group $\mathrm{C}$, those from group $\mathrm{E}$ had $27.8 \%$ higher body weight and $26.8 \%$ better liveweight gain, and were characterized by $18.7 \%$ better feed conversion ratio. Dressing percentage in group $\mathrm{C}$ was only slightly better (by 0.4 percentage points) than in group E. Carcass length and loin eye area were greater in group E than in group C. Carcass analysis showed greater amounts of meat and skin, and smaller amounts of fat and bones in the carcasses of E pigs compared to $\mathrm{C}$ pigs.

Van et al. (1997) used duckweed as a replacement for rice by-products (broken rice, rice bran) and other protein products (fish meal, soybean meal) in the diets of (Yorkshire $\times$ Landrace) $\times$ Baxuyen pigs with an initial body weight of $25.8 \mathrm{~kg}$. The control pigs (group C) were fed a concentrate containing broken rice $-60 \%$, rice bran $-33 \%$, soybean meal $-2 \%$, and fish meal $-5 \%$. In the experimental group $(\mathrm{E})$, animals were fed a diet composed of ensiled cassava root $-69 \%$, duckweed $-8.6 \%$, and supplements $-22.4 \%$. The use of the diet without rice by-products reduced the final body weight of the animals but feed conversion ratio in the groups was similar. The carcasses of E compared to C pigs were characterized by thinner backfat (by $8.6 \mathrm{~mm}$ ). The inclusion of $25 \%$ duckweed protein into the diets had no negative effect on the production results.

Gutierrez et al. (2001) fed pigs with dried duckweed. At the first stage of fattening, the pig rations were supplemented with $10 \%$ dried duckweed in place of sorghum and soybean meal (group E). Pigs from group $\mathrm{C}$ received sorghum, soybean meal, and a mineral-vitamin premix. There were no significant differences between treatments in live weight gain (group $\mathrm{C}-730 \mathrm{~g}$, group $\mathrm{E}-770 \mathrm{~g}$ ). Feed conversion ratio in groups $\mathrm{C}$ and $\mathrm{E}$ was similar and reached 2.93 and $2.96 \mathrm{~kg} / \mathrm{kg}$ body weight, 
respectively. Final body weight of the fattened pigs was $66.4 \mathrm{~kg}$ in group $\mathrm{C}$ and 69.8 $\mathrm{kg}$ in group E. It was concluded that $10 \%$ dried duckweed inclusion in a pig ration was beneficial in terms of production results.

Duckweed protein concentrate was produced and analyzed for its nutritive value to determine its potential use as a protein source for young pigs (Rojas et al., 2014). Duckweed protein concentrate, soybean meal, and fish meal were used in the experiment to determine metabolizable energy concentration, standardized total tract digestibility of phosphorus, and standardized ileal digestibility of amino acids. The content of metabolizable energy was higher in soybean meal than in duckweed concentrate and in fish meal. Standardized total tract digestibility of phosphorus was higher for duckweed protein concentrate than for soybean meal. Standardized ileal digestibility of amino acids was not different among ingredients. It was concluded that the analyzed feed ingredients did not differ in terms of nutrient values, which indicates that duckweed protein concentrate may be included in diets for young pigs.

\section{Ruminants}

Huque et al. (1996) studied the use of duckweed as a feed for cattle and determined its chemical composition as well as rate and extent of its digestion in the rumen. They concluded that various types of duckweed (Spirodela, Lemna and Wolffia) differ in the proximate composition. The evaluation of rate and extent of duckweed digestion showed that dry matter and crude protein are highly degradable in the rumen, therefore, further research is needed to assess the level of duckweed supplementation as cattle feed.

Damry et al. (2001) fed Merino ewes duckweed to determine its effect on the amount and characteristics of the wool. Sheep were fed oaten chaff in diet C (700 g/animal/day), $630 \mathrm{~g}$ oaten chaff and $50 \mathrm{~g}$ dried duckweed/animal/day in diet $\mathrm{E} 1,540 \mathrm{~g}$ oaten chaff and $100 \mathrm{~g} / \mathrm{animal} /$ day dried duckweed in diet E2, and $630 \mathrm{~g}$ oaten chaff and $1 \mathrm{~kg}$ fresh duckweed in diet E3. Sheep willingly ingested both fresh and dried duckweed, and the analyzed hair coat parameters (wool yield, rate of wool elongation, fiber diameter) did not differ among the groups. In the next trial, oaten chaff-based diets were enriched with urea (control group - C), cottonseed meal (experimental group $1-\mathrm{E} 1$ ), and dried duckweed meal (experimental group 2 - E2). In group C, the rate of fiber elongation was slower and wool yield lower than in groups E1 and E2. Fiber diameter was comparable among groups. It has been concluded that duckweed is a valuable source of protein for the ruminants.

An experiment with West African dwarf goats (Babayemi et al., 2006) aimed at determining if aquatic plants, such as aquatic fern and duckweed, can be potential sources of protein for the ruminants. In the preference test, goats were more eager to consume both fresh and dried duckweed than aquatic fern. Based on the results of the preference test, the authors conducted a balance trial in the next stage of the research, and concluded that fresh duckweed supplementation considerably increased nitrogen retention compared to the control diets based on guinea grass alone.

In a study by Reid (2004), Boer goats served as a model for the ruminants. They were fed dried duckweed as a replacement for soybean meal. There were four treatments and the diet for all groups was based on wheat hay, ground maize, and soybean 
hulls. Group C0 received no soybean meal, which was fed to animals from group C. Animals from group E1 had access to the feed in which $1 / 3$ of soybean meal was replaced with duckweed. In the experimental group E2, duckweed replaced 2/3 of the soybean meal. No differences were observed among the groups in nitrogen intake and nitrogen excretion, serum urea nitrogen level, and phosphorus intake and phosphorus excretion. Reid (2004) has concluded that duckweed is nutritionally comparable to soybean meal. It had no adverse effects on rumen $\mathrm{pH}$, amount of ammonium ions, and volatile fatty acids.

\section{Aquaculture - fish}

El-Shafai et al. (2004) investigated the effect of duckweed as a feed ingredient on Nile tilapia growth. The control diet contained fish meal, maize, wheat, wheat bran, fish oil, diamol, and premix. Part of the control diet ingredients was replaced in the experimental diet (experimental groups 1 and 2) with dry duckweed at 20 or $40 \%$ dry matter. In experimental groups 3 and 4, 20 and 40\% of fresh duckweed was used. Fish diets in these groups were based on the control diet ingredients. No differences were observed in growth rate between groups $\mathrm{C}$ and $\mathrm{E} 3$, and in other groups weight gains decreased. In all the groups, feed conversion ratio and protein efficiency ratio (PER) were comparable. Analysis of body composition indicated that tilapia fed dry or fresh duckweed had greater phosphorus and protein content and significantly lower lipid content. Tilapia fed the control diet had a higher dry matter content and lower ash content compared to fish from the experimental groups.

Tavares et al. (2008) conducted an experiment in which they analyzed performance of tilapia fed dried duckweed. Three diets were used: 1 - commercial feed (control group - C), $2-50 \%$ commercial feed $+50 \%$ dried duckweed (experimental group - E1), and 3 - dried duckweed (group E2). The final body weight of tilapia and the growth rate were comparable for groups $\mathrm{C}$ and $\mathrm{E} 1$. The lowest weight gain and the slowest growth rate were observed in group E2. Adding 50\% dried duckweed to the ration had no negative effect on tilapia growth.

Effiong et al. (2009) determined the possibility of partial replacement of fish meal with dried duckweed in the diet of Heterobranchus longifilis. The proportion of dried duckweed in the groups was: 0\% (group C), 10\% (E1), 20\% (E2) and 30\% (E3). Feed conversion ratio, growth rate and survival rate were determined. Increased duckweed inclusion in diets resulted in a reduced growth rate and body weight, and had a negative effect on feed conversion ratio. No differences were observed in growth parameters between groups $\mathrm{C}$ and E1. Survival rate differed among the groups at $87 \%$, $80 \%, 67 \%$ and $73 \%$, respectively.

\section{Aquaculture - shrimp}

Flores-Miranda et al. (2014) replaced fish meal with $0 \%, 3 \%, 5 \%, 10 \%$ or $15 \%$ of fermented duckweed in a diet for Pacific white shrimp (Litopenaeus vannamei), and concluded that duckweed may represent a potential source of protein to shrimps, however it needs to be explicitly confirmed in future research.

Consecutive investigations conducted by Flores-Miranda et al. (2015) demonstrated that fish meal replacement with $0 \%, 5 \%, 15 \%, 25 \%$ or $35 \%$ fermented duck- 
weed flour had no effect on shrimp survivability in all groups examined, and that the best growth efficiency was achieved in the group fed a diet with $35 \%$ inclusion of fermented duckweed flour.

\section{Future research}

Duckweed research should focus on analyzing the risks involved in the production, acquisition and processing of this protein source for animals. Due to its association with the aquatic environment, duckweed is vulnerable to accumulation of heavy metals, phenols, pesticides, dioxins, and pathogens. The Novel Food Catalogue, published by the European Commission, lists only one representative of duckweed, namely Lemna minor. Assessment of the safety of this species as a food or food ingredient for humans is now being carried out. According to Spiegel et al. (2013), the use of duckweed in feeds requires no authorization. Duckweed will probably be grouped as "fish, fish products, shell fish, molluscs and other marine and freshwater food products". Because there are currently no data on the maximum residue levels of plant protection products in duckweed, it would be appropriate to conduct relevant research. Experiments should be performed to provide the complete characteristics of secondary metabolites present in duckweed. The only toxic compound to animals, found and described in duckweed, is oxalic acid (Adeduntan, 2005). There is also less phytate in duckweed than in soybean meal (Rojas et al., 2014).

\section{Importance of duckweed for agricultural practice}

The development of biogas plants in Poland may contribute to the launching of large-scale duckweed production in our country. Agricultural biogas plants, which use cattle and/or pig slurry as the main feedstock, as well as supplemental maize silage, will produce large amounts of anaerobic digestate, which is a soil fertilizer (Bień and Bień, 2010). In addition, concentrated anaerobic digestate can be used to produce duckweed for feed purposes. Development of a proper duckweed production technology in greenhouses can largely contribute to increasing the amount of this protein source in the fresh form, and after processing also in the dried form. Very good accumulation of nutrients from growth media by duckweed may also help increase the amount of anaerobic digestate spread on grasslands and fields without endangering the environment.

\section{Conclusions}

It is concluded from the results of the studies cited above that fresh and/or dried duckweed is a potential source of plant protein for farm animals and aquaculture. Its use is limited by difficulties in harvesting fresh duckweed in some climatic zones as well as the high cost of producing processed feed. Current and future research addressing duckweed should focus on determining risks in its production, collection, and processing. 


\section{References}

A de d u n t a n S.A. (2005). Nutritional and antinutritional characteristics of some insects foragaing in Akure Forest Reserve Ondo State, Nigeria. J. Food Technol., 3: 563-567.

A h a m m a d M.U., S w a p on M.S.R., Ye a s m in T., R a h m a n M.S., A 1 i M.S. (2003). Replacement of sesame oil cake by duckweed (Lemna minor) in broiler diet. Pakistan J. Biol. Sci., 6: 14501453.

Akter M., Chowdhury S.D., Akter Y., Khatun M.A. (2011). Effect of duckweed (Lemna minor) meal in the diet of laying hen and their performance. Bangladesh Res. Public. J., 5: $252-261$.

Anders on K.E., Low man Z., S to m p A.M., Chang J. (2011). Duckweed as a feed ingredient in laying hen diets and its effect on egg production and composition. Int. J. Poultry Sci., 10: 4-7.

A ppenroth K.J., Sree K.S., Böhm V., Hammann S., Vetter W., Le iterer M., Jahre is G. (2017). Nutritional value of duckweeds (Lemnaceae) as human food. Food Chem., 217 : $266-273$.

B a b a y e mi O.J., B a mi k o le M.A., O mojola A.B. (2006). Evaluation of the nutritive value and free choice intake of two aquatic weeds (Nephrolepis biserrata and Spirodela polyrhiza) by West African dwarf goats. Trop. Subtrop. Agroecosyt., 6: 15-21.

B a iragi A., Sarkar-Ghosh K., S e n S.K., Ray A.K. (2002). Duckweed (Lemna polyrhiza) leaf meal as a source of feedstuff in formulated diets for rohu (Labeo rohita Ham.) fingerlings after fermentation with a fish intestinal bacterium. Bioresour. Technol., 85: 17-24.

B a n a s ze k A., M u s i ał K. (2009). The new kenophyte in Poland - Lemna minuta Humb., Bonpl. \& Kunth. Acta Societat. Botan. Polon., 78: 69-72.

B andurska K., B erdowska A., Król M. (2016). Transformation of medicinal plants using Agrobacterium tumefaciens (in Polish). Post. Hig. Med. Dośw., 70: 1220-1228.

B i én J., B i én B. (2010). Agricultural biogas plant as an element of waste management plant and green energy production in local municipality (in Polish). Inż. Ochr. Środ., 13: 17-27.

C e s c h in S., L e a c c he I., P a s c u c c i S., A b a t i S. (2016). Morphological study of Lemna minuta Kunth, an alien species often mistaken for the native L. minor L. (Araceae). Aquat Bot., 131: 51-56.

Chandra P., Kulshreshtha K. (2004). Chromium accumulation and toxicity in aquatic vascular plants. Bot. Rev., 70: 313-327.

Chhabra G., Chaudhary D., Sa inger M., Jaiwal P.K. (2011). Genetic transformation of Indian isolate of Lemna minor mediated by Agrobacterium tumefaciens and recovery of transgenic plants. Physiol. Mol. Biol. Plants, 17: 129-136.

$\mathrm{Ch}$ ojn a c k a K. (2006). The use of aquatic plants in the production of mineral feed additives (in Polish). Przem. Chem., 85: 1252-1255.

Cui W., Cheng J.J. (2015). Growing duckweed for biofuel production: a review. Plant Biol., 17: $16-23$.

C zerpak R., P i o trow s ka A. (2005). Wolffia arrhiza - the smallest plant with the highest adaptation ability and applications (in Polish). Kosmos. Probl. Nauk Biol., 54: 241-250.

D a m ry H., Nolan J.V., B ell R.E., Thom on E.S. (2001). Duckweed as a protein source for fine-wool Merino sheep: its edibility and effects on wool yield and characteristics. Asian-Australas. J. Anim. Sci., 14: 507-514.

D u T.H. (1998). Ensiled cassava leaves and duckweed as protein sources for fattening pigs on farms in Central Vietnam. Livest. Res. Rural Develop., 10: 3.

D u T.H., N g u y e n V.L., R o d ríg u e z L., Ly J. (1997). Nitrogen digestion and metabolism in Mong Cai pigs fed sugar cane juice and different foliages as sources of protein. Livest. Res. Rural Develop., 9: 2.

D u T.H., N guy e n Q.L., Everts H., B e ynen A.C. (2009). Ileal and total tract digestibility in growing pigs fed cassava root meal and rice bran with inclusion of cassava leaves, sweet potato vine, duckweed and stylosanthes foliage. Livest. Res. Rural Develop., 21: 1.

Effiong B.N., S anni A., F a kunle J.O. (2009). Effect of partial replacement of fishmeal with duckweed (Lemna pauciscostata) meal on the growth performance of Heterobranchus longifilis fingerlings. Rep. Opin., 1: 76-80. 
E1-Shafai S.A., E1-Gohary F.A., Verreth J.A.J., Schrama J.W., Gijzen H.J. (2004). Apparent digestibility coefficient of duckweed (Lemna minor), fresh and dry for Nile tilapia (Oreochromis niloticus L.). Aqua. Res., 35: 574-586.

F A O (1999). Duckweed - A tiny aquatic plant with enormous potential for agriculture and environment. FAO Publications, Rome, Italy.

Flores-Miranda M. del C., Luna-González A., Cortés-Espinosa D.V., Cortés - Jacinto E., Fierro-Coronado J.A., Álvarez-Ruiz P., González-Ocamp o H.A., Es c a milla-Montes R. (2014). Bacterial fermentation of Lemna sp. as a potential substitute of fish meal in shrimp diets. Afr. J. Microbiol. Res., 8: 1516-1526.

Flores-Miranda M. del C., Luna-González A., Cortés-Espinosa D.V., Álvarez-Ruiz P., Cortés-Jacinto E., Valdez-González F.J., Escamilla-Monte s R., G on zá le z-O c a m p o H.A. (2015). Effects of diets with fermented duckweed (Lemna sp.) on growth performance and gene expression in the Pacific white shrimp, Litopenaeus vannamei. Aquacult. Int., 23: 547-561.

G o o p y J.P., Murra y P.J. (2003). A review on the role of duckweed in nutrient reclamation and as a source of animal feed. Asian-Australas. J. Anim. Sci., 16: 297-305.

Gutierrez K., S angines L., P erez F., Marinez L. (2001). Use of studies on the potential of the aquatic plant Lemna gibba for pig feeding. Cuban J. Agric. Sci., 35: 343-348.

Gw a ze F.R., Mw a le M. (2015). The prospect of duckweed in pig nutrition. A review. J. Agric. Sci., 7: 189-199.

H a s a n M.R., C h a k r a b a r ty R. (2009). Floating aquatic macrophytes Duckweeds. In: Hasan M.R., Chakrabarty R. (Eds). Use of algae and aquatic macrophytes as feed in small-scale aquaculture a review. Food and Agriculture Organization of the United Nations (FAO), Rome, pp. 29-52.

H a s s a n M.S., E d w a r d s P. (1992). Evaluation of duckweed (Lemna perpusilla and Spirodela polyrrhiza) as feed for Nile tilapia (Oreochromis niloticus). Aquacult., 104: 315-326.

H a u s t e in A.T., G 11 m a n R.H., S ki 11 i c or n P.W., G u e va ra V., D i a z F., Verg a ra A., G 11 m a n J.B. (1992). Compensatory growth in broiler chicks fed on Lemna gibba. Brit. J. Nutr., 68: $329-335$.

Ha us te in A.T., Gilman R.H., Skillic orn P.W. (1994). Performance of broiler chickens fed diets containing duckweed (Lemna gibba). J. Agric. Sci., 122: 285-289.

Huque K.S., Chowdhury S.A., Kibra S.S. (1996). Study on the potentiality of duckweeds as a feed for cattle. Asian-Australas. J. Anim. Sci., 9: 133-137.

I q b a 1 S. (1999). Duckweed Aquaculture. Potentials, Possibilities and Limitations for Combined Wastewater Treatment and Animal Feed Production in Developing Countries. SANDEC Report No. 6/99.

K a b i r J., I s 1 a m M.A., A h a m m a d M.U., H o w 1 i d e r M.A.R. (2005). Use of duckweed (Lemna minor) in the diet of broiler. Indian J. Anim. Res., 39: 31-35.

Kh a nd a ker T., Khan M.J., Sh a h j a l a 1 M., R a h m a n M.M. (2007). Use of duckweed (Lemna perpusilla) as a protein source feed item in the diet of semi-scavenging Jinding layer ducks. J. Poult. Sci., 44: 314-321.

K h a n g N.T.K. (2003). Use of duckweed (Lemna minor) as a protein supplement for local (Tau Vang) chicks, and growing and laying hens (MSc Thesis, MEKARN-SLU).

Khan u m, J., Chwalibog A., Huque K.S. (2005). Study on digestibility and feeding systems of duckweed in growing ducks. Livest. Res. Rural Develop., 17: 5.

L a s s o c ińs ki W. (1979). Duckweed grown on wastewater as a supplementary source of protein (in Polish). Wszechświat, 10: 232-234.

L e n g R.A., S t a m b o li e J.H., B e 11 R. (1995). Duckweed - a potential high-protein feed resource for domestic animals and fish. Livest. Res. Rural Develop., 7: 1.

Ly J., S a m k o 1 P., Pre s t o n T.R. (2002). Nutritional evaluation of aquatic plants for pigs: pepsin/ pancreatic digestibility of six plant species. Livest. Res. Rural Develop., 14: 1.

M e n L.T., B u i H.V., M a i T.C., Pre s t on T.R. (1997). Effect of dietary protein level and duckweed (Lemna spp.) on reproductive performance of pigs fed a diet of ensiled cassava root or cassava root meal. Livest. Res. Rural Develop., 9: 1.

M o he d a no R.A., C o s t a R.H.R., Tav are s F.A., Fil ho B.P. (2012). High nutrient removal rate from swine wastes and protein biomass production by full-scale duckweed ponds. Bioresour. Technol., 112: 98-104. 
M o s s B.S. (1999). Economics and feed value of integrating duckweed production with a swine operation. Submitted to the Graduate Faculty of Texas Tech. University in Master of Science, Texas University.

M o y o S., D a lu J.M., Nd a m b a J. (2003). The microbiological safety of duckweed fed chickens: a risk assessment of duckweed fed chickens: a risk assessment of using duckweed reared on domestic wastewater as a protein source in broiler chickens. Phys. Chem. Earth., 28: 1125-1129.

Mwale M., Gwaze F.R. (2013). Characteristics of duckweed and its potential as feed source for chickens reared for meat production. A review. Sci. Res. Essays., 8: 689-697.

N e w m a n J. (2013). Information Sheet 16: Duckweeds. Centre for Ecology \& Hydrology.

Ngamsaeng A., Thy S., Preston T.R. (2004). Duckweed (Lemna minor) and Water spinach (Ipomoea aquatic) as protein supplements for ducks fed broken rice as basal diet. Livest. Res. Rural. Develop., 16: 18-24.

$\mathrm{N}$ g u y e $\mathrm{n}$ V.L. (1998). On-farm comparison of Mong Cai and Large White pigs fed ensiled cassava root, rice bran and duckweed. Livest. Res. Rural Develop., 10: 3.

Olorunfemi T.O.S., Aderibigbe F.M., A lese B.K., Fasakin E.A. (2006). Utilization of duckweed (Lemna paucicostata) in least cost feed formulation for broiler starter: A linear programming analysis. Inf. Technol. J., 5: 166-171.

Piotrowska A., Bajguz A., Godlewska-Żyłkiewicz B., Czerpak R., Kamińs k a M. (2009). Jasmonic acid as modulator of lead toxicity in aquatic plant Wolffia arrhiza (Lemnaceae). Environ. Exp. Bot., 66: 507-513.

Piotrowska A., Bajguz A., Godlewska-Żyłkiewicz B., Zambrzycka E. (2010). Changes in growth, biochemical components, and antioxidant activity in aquatic plant Wolffia arrhiza (Lemnaceae) exposed to cadmium and lead. Arch. Environ. Contam. Toxicol., 58: 594-604.

R e id D.W.S. (2004). Exploring duckweed (Lemna gibba) as a protein supplement for ruminants using the Boer goat (Capra hircus) as a model. A thesis submitted to the Graduate Faculty of North Carolina State University.

Rodríguez L., Preston T.R. (1996). Comparative parameters of digestion and N metabolism in Mong Cai and Mong Cai Large White cross piglets having free access to sugar cane juice and duck weed. Livest. Res. Rural Develop., 8: 5.

Rojas O.J., Li u Y., S te in H.H. (2014). Concentration of metabolizable energy and digestibility of energy, phosphorus, and amino acids in lemna protein concentrate fed to growing pigs. J. Anim. Sci., 92: 5222-5229.

Romanowska-Duda Z., Pszczółkowski W. (2013). Lemnaceae biomass as an alternative substrate for renewable energy (in Polish). Acta Innovat., 9: 25-33.

R o o ijakkers P. (2016). Photosynthesis model to predict duckweed growth at the Ecoferm greenhouse. Bachelor thesis, Wageningen University\& Research.

R u s off L.L., Z e ring u e S.P., A ch a c o s o A.S., Culley D.D. (1978). Feeding value of duckweed (an aquatic plant, Family Lemnaceae) for ruminants. The American Dairy Science Association Michigan State University, East Lansing, Mich. July 9-13.

R u s off L.L., B l a k e n e y E.W., C u 11 e y D.D. (1980). Duckweeds (Lemnaceae): A potential source of protein and amino acids. J. Agric. Food Chem., 28: 848-850.

$\mathrm{S}$ a $\mathrm{m} n$ a $\mathrm{n}$ H. (1999). Duckweed versus ground soya beans as supplement for scavenging native chickens in an integrated farming system. Livest. Res. Rural Develop., 11: 1.

S an s oucy R. (1995). New developments in the manufacture and utilization of multi-nutritional blocks. Rev. Mondial de Zootech., 72: 82-83.

$\mathrm{S}$ h ow q i I., L o n e F.A., B h a t.I.A. (2017). Evaluation of the efficiency of duckweed (Lemna minor L.) as a phytoremediation agent in wastewater treatment in Kashmir Himalayas. J. Bioremediat. Biodegrad., 8: 405, DOI: 10.4172/2155-6199.1000405.

S i k o r a J., M a l in ow s k i M. (2015). Effect of duckweed in the substrate for the energy use of digestate (in Polish). Proc. ECOpole, 9: 2, DOI: 10.2429/proc.2015.9(2)085.

S p i e g e 1 M., N o o r d a m M.Y., F e ls - K l e r x H.J. (2013). Safety of novel protein sources (insects, microalgae, seaweed, duckweed and rapeseed) and legislative aspects for their application in food and feed production. Compr. Rev. Food Sci. Food Saf., 12: 662-678.

Tavares F.A., Rodrigues J.B.R., Fracalos si D.M., Es quivel J., Roubach R. (2008). Dried duckweed and commercial feed promote adequate growth performance of tilapia fingerlings. Biotemas, 21: 91-97. 
Van B.H., M en L.T., S on V.V., P re s t on T.R. (1997). Duckweed (Lemna spp.) as protein supplement in an ensiled cassava root diet for fattening pigs. Livest. Res. Rural Develop., 9: 1.

Verma R., Suthar S. (2014). Synchronized urban wastewater treatment and biomass production using duckweed Lemna gibba L. Ecolog. Engineer., 64: 337-343.

V l a d i m i r o va I.N., G e or g i y a $\mathrm{t}$ s V.A. (2014). Biologically active compounds from Lemna minor. Pharm. Chem. J., 47: 599-601.

Witkowska Z., S a ei d A., Chojnacka K., Dobrzański Z., Górecki H., Michalak I., Korczyński M., O pa liński S. (2012). New biological dietary feed supplement for laying hens with microelements based on duckweed (Lemna minor). Am. J. Agri. Biol. Sci., 7: 482-493.

W ó j c i a k H., U r b a n D. (2007). Duckweeds (Lemnaceae) and their phytocenoses in old river-beds of the Bug River valley (between Kryłów and Kostomłoty) (in Polish). Water-Enviromental-Rural Areas, 9: 215-225.

Y i $1 \mathrm{~m}$ a z E., A k u rt I., G ün a l G. (1994). Use of duckweed, Lemna minor, as a protein feedstuff in practical diets for common carp, Cyprinus carpio, fry. Turk. J. Fish. Aquatic Sci., 4: 105-109.

Z aw a d zki K. (2016). Possibilities for the use of natural high-protein raw materials (duckweed and flies) for feed purposes (in Polish). Przegl. Zboż. Młyn., 1: 53.

Zha o Z., Shi H., Li u Y., Zh a o H., S u H., Wang M., Zh a o Y. (2014). The influence of duckweed species diversity on biomass productivity and nutrient removal efficiency in swine wastewater. Bioresour. Technol., 167: 383-389.

Received: 9 V 2018

Accepted: 4 X 2018 